\title{
A new species of Embsaygnathus (Conodonta) from the Arundian (Carboniferous) of Co. Dublin, Ireland.
}

\author{
GARETH LI. JONES \\ Conodate International Ltd, 7A Olivemount Terrace, Windy Arbour, Dublin 14, Ireland
}

\begin{abstract}
Embsaygnathus crosbiei sp. nov. Jones is recorded from Arundian limestones at Newcastle, Co. Dublin, Ireland. It is suggested that E. crosbiei and Embsaygnathus asymmetricus Metcalfe were derived from the Geniculatus claviger Roundy - Geniculatus glottoides Vosges lineage.
\end{abstract}

\section{INTRODUCTION}

Investigation for Chevron Mineral Corporation of Ireland, of the 130m deep borehole CN/NC-18 (Grid ref. N 998 286), at Newcastle, $17 \mathrm{~km}$ east-south-east of Dublin, produced a conodont fauna at $4.0 \mathrm{~m}$ depth, including Embsaygnathus crosbiei sp. nov. described here. Foraminifera from the same level confirmed the Arundian age. Processing of further intervals from the drill core failed to produce any more examples of this species, but a specimen of Embsaygnathus asymmetricus Metcalfe 1981 and several specimens of Geniculatus claviger Roundy 1926 emended Hass 1953 were recovered. It is considered that this new species may be an intermediate form on the evolutionary pathway from Ge. claviger to E. asymmetricus (see Fig. 1). Examples of recurved or geniculate platform conodonts are rare in the Dinantian. It is unusual to erect a new species on the strength of one specimen, but occurrences of the genus are rare and it is thought unlikely that further examples will be recovered for some time. Enquiries from other workers in this area and processing of available material have failed to produce any more examples. Since it is considered to be an important link in the evolutionary story of rare recurved and geniculate platform conodont elements, it was considered worthwhile publishing.

The rarity of this conodont animal also means that only the Paelement is described here, the determination of the rest of the apparatus must wait until more evidence has been gathered.

The holotype and other figured specimens are presently stored in the micropalaeontology collection of Conodate International Ltd. They will eventually be reposited in the collection of the National Museum of Ireland numbers NMING: F20941-7.

\section{MICROPALAEONTOLOGY}

Metcalfe (1981) first described E. asymmetricus from the Craven lowlands of nothern England. He recovered three specimens from the G. homopunctatus Biozone (Chadian and Arundian) of the
Embasy Limestone of Embasy Bank, Skipton, Yorkshire. Since then a few further individuals have been recorded, making a total of eight. Swift recovered a single specimen from the commutata Zone (Arundian -?lower) of the Isle of Man, Ronaldsway Member, Derbyhaven Formation (Varker \& Sevastopulo 1985, Pl. 5.6, Figs 11 \& 16), Reynolds found the species in the Visean Limestones of the Eshton and Rylston areas of the Craven Basin (in Metcalfe 1980).

Two specimens are reported here. One (Pl. 1, Figs 5, 6) from Dublin Basin Group Limestones in CN/NC-18, 26.2-31.2m (Arundian, Newcastle, Co. Dublin and a second (Pl. 1, Figs 3, 4) from Pettigoe Limestone, Pettigoe, Co. Donegal (Grid ref. H 108673), also Arundian. Since it is possible that the Embsay Limestone is restricted to the Arundian (N Riley pers. comm. 1987) it is likely that the range of E. asymmetricus is also restricted to the Arundian.

The other genus discussed here is Geniculatus Hass 1953. Examples of Ge. Claviger are not uncommon and range throughout the Dinantian, but the species Ge. glottoides Vosges 1959 is rare. Previously recorded specimens of Ge. glottoides include one from the $L$. commutata Zone (Arundian) at Reenydonagen, Co. Cork, (Varker and Sevastopulo 1985, Pl. 5.6, figs 5, 6) whilst Voges' (1959) twenty specimens were recorded from the junction of the "Liegende Alaunschiefer" - the predominantly Hydrite horizon (cull/anchoralis Zone) of Bömighausen, W. Germany. Groessens found a single reworked specimen in V3b $\gamma$ Chert Limestones in the Houthem borehole DB105 in Holland (in Bless et al. 1976), the only recorded specimen of this age, but probably derived from older rocks.

This paper reports two specimens from the Dublin Basin. The first (Pl. 1, Figs 7, 10) from the Arundian in Chevron borehole KN1, 31.0-35.0m (Pl. 1, Figs 10, 11) at Kinnegad, Co. Meath, 50km west of Dublin (Grid ref. N 560428). Another (Pl. 1, Fig. 7) was recovered from the Chadian in Chevron borehole OT-9, 12.8-19.0m at Oldtown, Co. Dublin, 20km north of Dublin (Grid ref. O 1 19543). 


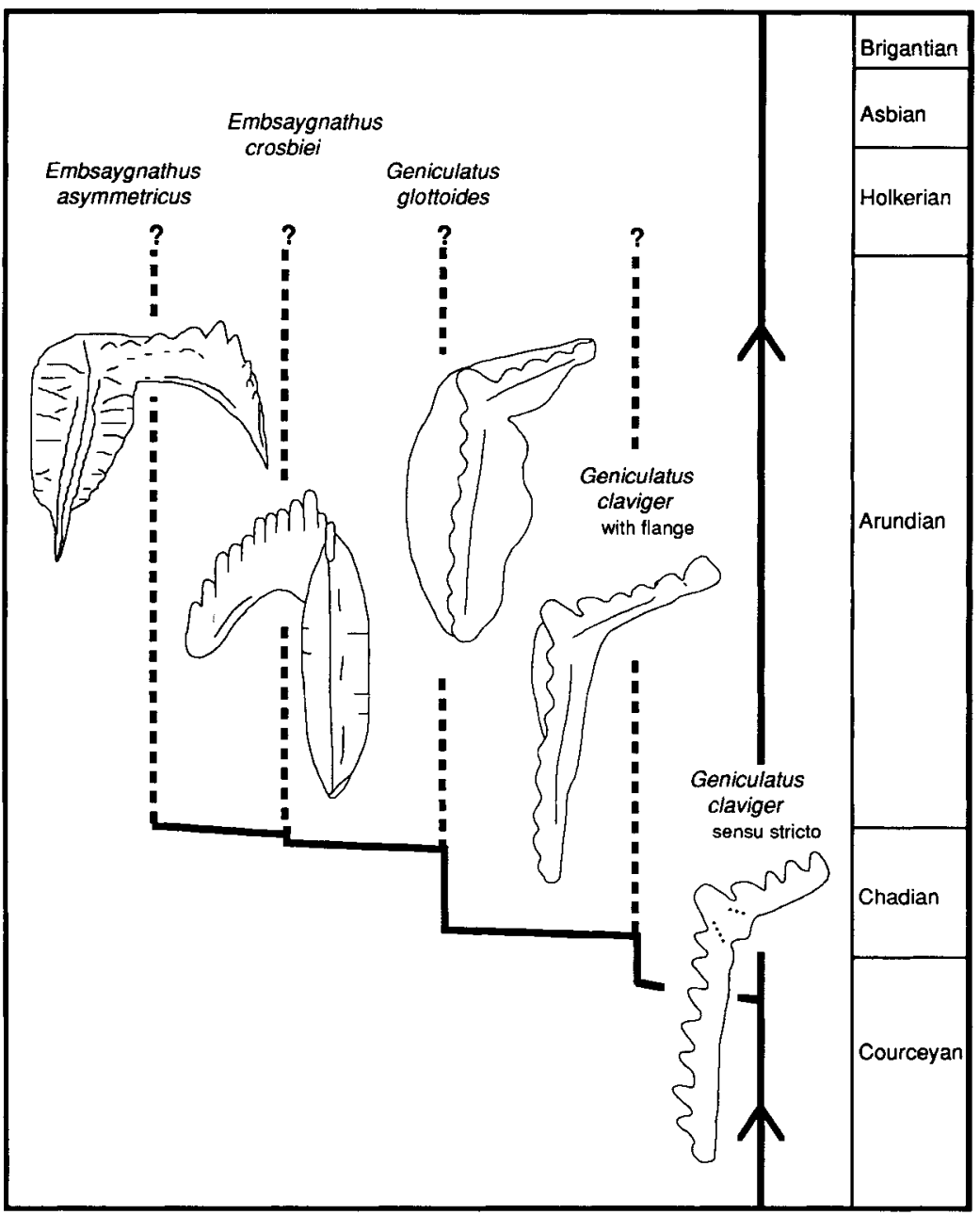

Fig. 1. Suggested phylogeny of GeniculatusEmbsaygnathus during the Chadian and Arundian Stages of the Dinantian Subsystem.

\begin{abstract}
SYSTEMATICS
Order Conodontophorida Eichenberg 1930 Genus Embsaygnathus Metcalfe 1981

Type species Embsaygnathus asymmetricus Metcalfe 1981

The orientation of the element has been inverted from Metacalfe's description, so that anterior and posterior are reversed, i.e. It is the anterior bar that is strongly recurved, and the platform continues with a posterior bar.
\end{abstract}

Embsaygnathus crosbiei sp. nov.

(Pl. 1, figs 1; 2)
Derivation of name. This species is named in honour of the late Dr Crosbie Matthews of Bristol University, and in memory of his strong associations with Ireland.

Diagnosis. A species of Embsaygnathus having a straight platform with restricted ornament. The carina carries four fused blunt denticles. Holotype. NMING: F20941; Pa element.

Type locality and horizon. Chevron borehole $\mathrm{CN} / \mathrm{NC}-18$ : at a depth of $4.0 \mathrm{~m}$. Grid ref. N 998 286. Lucan Formation, calciturbidite, Arundian Stage, Dinantian Subsystem.

Range. Since only one specimen of E. crosbiei has so far been recorded, it is not possible to define a range. However its recovery

\section{Explanation of Plate 1}

Figs 1, 2

Figs 3-6

Figs $7,10,11$

Figs 8.9

Figs 12, 13
Embsaygnathus crosbiei Jones, Pa element, Holotype NMING:F20941; Chevron borehole CN/NC-18, 4.0m Newcastle, Co. Dublin, (Grid ref. N 998 286). Fig. 1, oral view; note scar where posterior process may have been broken off; Fig. 2 aboral view.

Embsaygnathus asymmetricus Metcalfe; Figs 3, 4, NMING:F20942, Pettigoe Limestone, Pettigoe, Co. Donegal, (Grid ref. H108673). Figs 5, 6, NMING:F20943 Chevron borehole CN/NC-18, 26.1-31.2m, Newcastle, Co. Dublin; Figs 3, 5, oral views; Figs 4, 6, aboral views. Geniculatus glottoides Voges; Fig. 7, NMINGH:F20944, Chevron borehole OT-9, 12.8-19.0m, Oldtown, Co. Dublin, (Grid ref. O 119543 ). Figs 10, 11, NMING:F20945 Chevron Borehole KN-1,31-35m, Kinnegad, Co. Meath (Grid ref. N560428); Figs 7, 10, oral views; Fig. 11 , aboral view.

Geniculatus claviger Hass, specimen with flanges.

Geniculatus claviger Hass sensu stricto, NMING:F20947, Chevron borehole KN-1, 31-35m Kinnegad, Co. Meath. Fig. 12, oral view; Fig. 13 , aboral view. 


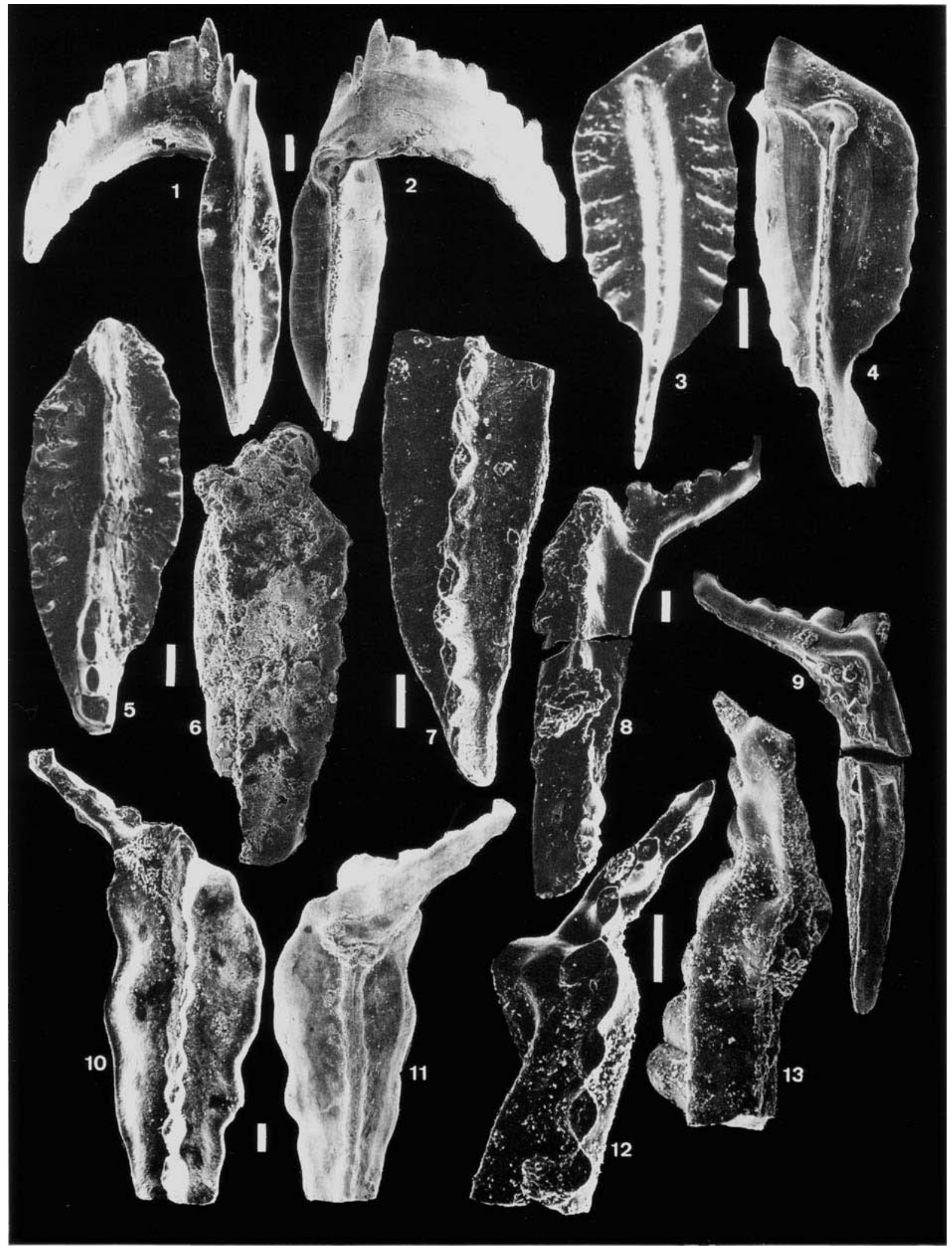


from mid Arundian limestones is within the established range of Embsaygnathus, which runs from late Chadian to Arundian(Metcalfe 1981).

Description. E. crosbiei is strongly recurved and possesses a narrow platform with restricted ornament. The anterior bar extension curves outwards and then to the posterior through a total of $160^{\circ}$. The small basal cavity is subcircular and located at the junction of the platform and the anterior bar which are both keeled.

\section{ASSOCIATED FAUNA}

The sample at $4 \mathrm{~m}$ from $\mathrm{CN} / \mathrm{NC} 18$ yielded the Pa elements $E$. crosbiei sp. nov. (1) and Mestognathus beckmanni Bischoff 1957 (7). Also recovered were other elements, here given their separate element taxonomy; Ozarkodina sp. (3), Neoprioniodus sp. (3), Hindeodella (1), Hibbardella (Hibbardella) sp. (1), and "Apatognathus" sp. (1). Two fish teeth were also recovered.

The yield of eight $\mathrm{Pa}$ elements $/ \mathrm{kg}$ is high for Dublin Basin calciturbidites, except when they possess coarse bases. The presence of Mestognathus indicates the shallow water origin of this reworked fauna and suggests that $E$. crosbiei may also have been a shallow water animal.

Remarks. E. crosbiei differs from E. asymmetricus in the following features. The platform is narrow and symmetrical but bears only two to four low nodes on the edges, whereas there are eight to ten transverse ridges on the wide platform of $E$. asymmetricus. In lateral view it is straight without the arch seen in E. asymmetricus. The sharp carina develops only four blunt fused nodes posteriorly instead of thirteen to fourteen. There is a shallow trough on each side of the carina. E. asymmetricus carries no main cusp which is a feature of Geniculatus, but $E$. crosbiei does bear a strong denticle at the start of the anterior blade. Metcalfe (1981) describes the recurved blade of $E$. asymmetricus as being a posterior bar, but it is considered here that it is the anterior bar which is recurved and compares with the geniculate anterior bar of Geniculatus (Fig. 1 and Table 1). In E. asymmetricus the anterior blade curving outwards and posteriorly through a total of $170^{\circ}$, carries ten denticles which slope towards the anterior. In $E$, crosbie $i$ the carina continues towards the anterior into a strong blade, with ten sharp denticles, which curves to the posterior through $160^{\circ}$ (Table 2).

In both species of Embsaygnathus the arboral surface is strongly keeled, as opposed to that of Geniculatus which is grooved (Table 2). In E. asymmetricus the anterior keel diverges from the cavity at $110^{\circ}$ whilst in E. crosbiei it diverges at $100^{\circ}$. In E. crosbiei the basal cavity is also found at the anterior end at the junction of the platform and blade, it is small subcircular and flared, and slightly pointed to the posterior.

This new species clearly falls within Embsaygnathus although it does bear similarities to Geniculatus (Tables 1 and 2).

\section{PHYLOGENY}

Examination of a number of specimens of Ge. claviger revealed a variation in the width of the posterior bar. An example found at 20.7$25.4 \mathrm{~m}$ from CN/NC-18 (Pl. 1 and Fig. 1) carries a flange which is broadest at the anterior and tapers posteriorly. Thornbury (1985) figured a specimen with a broad flange from the $D$. latus Subbiozone of the $S$. anchoralis Biozone (late Courceyan), at Ballygarvan, Co. Cork. This form appears to be a morphological intermediate between Ge. claviger sensu stricto and Ge. glottoides, and it is likely that it is from such a variant that E. crosbiei is derived (Fig. 1). It is envisaged that the broad flange enlarged into the somewhat plain platform of $E$. crosbiei which then went on to develop into the well ribbed platform of $E$. asymmetricus. Evidence for the transition of the anterior bar from the stubby geniculate form of Geniculatus, to the strongly recurved form of Embsaygnathus has not yet been seen. Morphological comparisons of these forms are seen in Tables $1 \& 2$. The combination of all the features described and illustrated in Table 2 excludes the possibility that E. crosbiei is an aberrant form of E. asymmetricus.

It is interesting to speculate from the form similarities, that the lineage may have had its origins in the Devonian from Palmatolepis (Tripodellus) gracilis, and may have given rise in the Silesian to Neogondolella.

\section{ACKNOWLEDGEMENTS}

I am indebted to Chevron Mineral Corporation of Ireland and to Murry Hitzman for permission to use material from their boreholes. I gratefully thank Ian Somerville who made useful criticisms of the manuscript and John Kelly for photographic assistance. Also the members of the conodont group of the British Micropalaeontological Society for informed discussion, and an anonymous referee for pertinent amendments. In particular I wish to thank Sam Ellis for kind remarks and encouragement.

Manuscript received April 1989

Manuscript accepted May 1991

\section{REFERENCES}

Bless, M.J.M., Bouckaert, J., Bouzet, P.H., Conil, R., Cornet, P., FaironDemaret, M., Groessens, E., Longerstaey, P.J., Meesen, J.P.M.T.H., Paproth, E., Pirlet, H., Streel, M. Van Ameron, H.W.J. \& Wolf, M. 1976. Dinantian rocks in the subsurface North of the Brabant and ArdennoRhenish massifs in Belgium, the Netherlands and the Federal Republic of Germany. Mededelingen Rijks Geologische Dienst Nieuwe Serie 27, 3.

Dickson, J.A.D., Ford, T.D. and Swift, A. 1987. The stratigraphy of the Carboniferous rocks around Castletown, Isle of Man. Proc, Yorks. Geol. Soc. 46, 3, 203-229.

Hass, W.H. 1953. Conodonts of the Barnett Formation of Texas. U.S. Geol. Surv. Prof. Pap.243-F, 69-94.

Metcalfe, I. 1980. Conodont faunas and age of the Raygill Quarry Limestones (Embsay Limestone), Lothersdale, Yorkshire. Proc. Yorks. Geol. Soc. 43, 2, 169-178.

Metcalfe, I. 1981. Conodont zonation and correlation of the Dinantian and early Namurian strata of the Craven Lowlands of northern England. Inst. Geol. Sco. Rept. 80/10, 1-70.

Roundy, P.V. 1926. Introduction, the microfauna in Mississippian formations of San Saba County, Texas by Roundy and others. U.S. Geol. Surv. Prof. Pap. 146, 63p.

Thornbury, B.M. 1985. Conodont biostratigraphy of Dinantian rocks from the Cloyne Syncline, Co. Cork. Unpub. M.Sc. thesis, Univ. of Dublin.

Varker, W.J. \& Sevastopulo, G.D. 1985. Conodonts of the Dinantian Subsystem from Great Britain and Ireland. p. 167-209. In Higgins, A.C. \& Austin, R.A. (Eds) A Stratigraphical Index of Conodonts, Ellis Horwood, Chichester, 263pp.

Voges, Von A. 1959. Conodonten aus dem Untercarbon I und II (Gattendorfieund Pericyclus-Stufe) des Sauerlandes. Paleont. Z. 33, 4, 266-314. 


\begin{tabular}{|c|c|c|}
\hline & Geniculatus Hass 1953 & Embsaygnathus Metcalfe 1981 \\
\hline Type species & Ge. claviger Roundy 1926 & E. asymmetricus Metcalfe 1981 \\
\hline Outline & geniculate & recurved. \\
\hline Posterior & denticulate bar tapering from apex. & platform with posterior blade \\
\hline Platform & $\begin{array}{l}\text { Not in the type species, although some } \\
\text { forms may develop flanges along the } \\
\text { posterior bar. The species Ge. gloddoides. } \\
\text { develops a smooth crenulate platform }\end{array}$ & present, cf Polygnathus \\
\hline Anterior & $\begin{array}{l}\text { denticulate bar tapering from apex } \\
\text { angled inwards. Ge. glottoides develops } \\
\text { a small platform along this bar. }\end{array}$ & $\begin{array}{l}\text { bar extension curves outwards and } \\
\text { then towards the posterior. }\end{array}$ \\
\hline Main Cusp & situated at vertex. & $\begin{array}{l}\text { absent, or a strong denticle at start } \\
\text { of anterior blade. }\end{array}$ \\
\hline Cavity & $\begin{array}{l}\text { small, located at junction of anterior } \\
\text { bar and platform, beneath main cusp. }\end{array}$ & $\begin{array}{l}\text { small, located at junction of anterior } \\
\text { blade and platform. }\end{array}$ \\
\hline Aboral surface & grooved along midline. & keeled. \\
\hline
\end{tabular}

Table 1. Comparison of the morphological characters of Geniculatus and Embsaygnathus.

\section{E. asymmetricus Metcalfe 1981}

Posterior blade

$25 \%$ of platform, 4 denticles

Platform

Main cusp

Anterior blade

Aboral surface

Cavity wide and symmetrical, 8-10 transverse ridges, carina with 13-14 fused blunt denticles, trough on each side of carina.

absent.

row of nodes or denticles at right angles to carina develop outwards into an anterior bar with 10 denticles sloping towards the anterior. It then curves towards the posterior through (a further 800).

strongly keeled the anterior keel diverges from the cavity at $110^{\circ}$.

at the anterior end at the junction of the platform and anterior bar. It is small, subcircular, strongly flared with extended lips. It is slightly pointed towards the posterior and extends along platform and anterior bar as grooves.

\section{E. crosbiei Jones 1991}

May have been broken off

narrow and symmetrical, 2-4 nodes on edges, sharp carina develops 4 blunt fused nodes towards the posterior trough on each side of carina.

start of anterior blade bears a strong denticle.

carina continues anteriorly into a strong blade with 10 sharp denticles which curves posteriorly through $160^{\circ}$.

strongly keeled, the anterior keel diverges from the cavity at $100^{\circ}$.

at the anterior end at the junction of the platform and blade. It is small, subcircular flared. It is slightly pointed towards the posterior.

Table 2. Morphological comparison of Embsaygnathus asymmetricus and Embsaygnathus croshiei. 